\title{
Varieties and Variations of Functional Differentiation
}

\author{
Boris Holzer*
}

\begin{abstract}
Functional differentiation is associated with two salient features of globalization: First, societal subsystems such as the economy, science, religion and politics have become increasingly global in terms of the interconnectedness of their operations across the world. Second, they exhibit global structural similarities, for instance regarding functionally specific role relationships and corresponding formal organizations. However, functional differentiation entails not only more interconnectedness and homogenization but also considerable structural and institutional diversity. In this paper, I distinguish and examine two forms of diversity that emerge as consequences of functional differentiation: Varieties of institutional structures that concern different ways of addressing functionally specific problems, on the one hand, and on the other, the variation of forms of structural coupling among subsystems within a particular local or regional context.
\end{abstract}

The debate about globalization, like other controversies in sociology, oscillates between extremes: It has highlighted global homogenization as well as regional and cultural diversification, secular trends as well as contingent developments, and increasing differentiation as well as global integration. Concepts such as 'hybridization' or 'glocalization' have been put forward to reconcile seemingly contradictory arguments. Yet efforts to integrate them into a coherent theoretical framework have been few and far between. ${ }^{1}$ At first glance a 'theory of world society' appears to be an unlikely candidate to provide such a framework. ${ }^{2}$ How can the concept of a singular global society address the heterogeneous and uncoordinated character of worldwide social relationships? Do persisting inequalities, a lack of collective agency and cultural differences make it implausible to speak of one society? However, the concept of society by no means implies that living standards need to be the same. Equality of that sort cannot be presumed within the borders of any nation-state - nor even any major city but so far, no one has rejected the idea of an 'American society' based on that fact alone. Inequality and difference are not arguments against world society but for examining the mechanisms of their reproduction at the global level (Luhmann 1997, 145ff.; Stichweh 2000). In the following sections I will first discuss the relationship between globalization and functional differentiation. The argument that differentiation goes hand in hand with

\footnotetext{
* Corresponding author: Prof. Boris Holzer, Ph.D., University of Konstanz, Department of History, Sociology, Empirical Educational Research and Sport Science, P.O. Box 28, D-78457 Konstanz

1 The most notable exception is Robertson's (1992) seminal contribution.

2 For critical statements see Wagner (1996) and Schwinn (2004).
} 
globalization is seminal for a theory of world society, whereas the question of variations of functional differentiation, which I address in the following section, may be considered as a theoretical challenge. There are, however, fruitful ways to address and theorize modifications of the 'Western' model of modernity. In what follows I will distinguish between two forms of diversity associated with - and indeed fostered by - functional differentiation: varieties of institutional structures that emerge in response to functionally specified problems, on the one hand, and on the other, institutional variations that modify structural templates. In particular, I will discuss functional differentiation as a source of global expansion but also of institutional variety, variations of coupling and decoupling and, finally, the question of the primacy of functional differentiation at the global and local level.

\section{Globalization and functional differentiation}

From the perspective of the theory of functional differentiation, globalization cannot be regarded as an exogenous process affecting territorially bounded societies. Globalization is a consequence of the emergence of functional subsystems. Societal subsystems such as the economy, science, religion, education and also politics may be regarded as 'global' systems in at least two ways: first, in terms of interconnectedness, which makes events in distant places highly interdependent (like, for instance, prices in the world economy); second, in terms of specific social structures that characterize particular subsystems across the world, e.g. professional roles such as politicians, teachers or scientists as well as organizations such as ministries, schools or universities. From either angle, many social fields reveal a high degree of globalization: Science does not know 'Indian' truths that would be different from 'American' ones; Muslims have to pay their bills, and they cannot do so with beliefs alone; educational certificates may need to be translated, but the reasons for producing and indeed comparing them are very much the same around the world. Such observations do not deny the significance of regional particularities. Functional differentiation does not necessarily entail a complete convergence on the level of institutions and practices. Statements about 'science' or the 'economy' in world society must therefore beware of the 'ecological fallacy' and not confuse broad descriptions of typical or average conditions with the adequate description of individual cases and practices (Holzer 2006). In contrast to classic modernization theory, the theory of world society does not need to expect convergence and homogeneity. Neither does it need to assume that European or 'Western' developments are replicated elsewhere. 
The assertion that functional differentiation is not a theory of global convergence requires some elaboration: Differentiation theory is one of the key elements of classic modernization theory and therefore, one might assume, associated with a one-dimensional and linear understanding of social change. But its point of departure is difference (e.g. between societal subsystems) rather than uniformity (e.g. in terms of normative integration). The globalizing dynamics of functional differentiation are not due to an encompassing and comprehensive process of societal globalization but rather due to the 'specific universalism' of societal subsystems, i.e. the way in which each subsystem adopts its own criteria of relevance. Within the specific interests of their functional domain, subsystems adopt a universalistic perspective, i.e. they observe anything and everything under the auspices of their 'code.' From the perspective of the economy, anything may be monetized; from the perspective of science, anything and everything may be subject to scientific investigation; and from the perspective of the political system, anything may be turned into a matter of collective decision-making. Generally speaking, expansion is therefore a correlate of the functional specialization of societal subsystems.

The notion of universalism implies some degree of homogeneity within particular social fields. But it would be too simple to juxtapose the diversity among subsystems with uniformity within them. We cannot explain every kind of diversity as a result of functional differentiation and specialization; there are other, e.g. cultural differences that straddle the boundaries of functional systems. And subsystems are not homogeneous social fields but also produce internal differences, inequalities and variations. Luhmann argues that the operational logic of subsystems increases rather than decreases differences and that their differential impact - and therefore their capacity to generate heterogeneity - is greater in some regions than in others (Luhmann 2005, 78; 1997, 163ff.). The basic scheme of functional differentiation should therefore not be considered the only possible answer to the question of global diversity. Rather, it should be regarded as a useful point of departure for investigating the relationship between the homogenizing and heterogenizing effects of globalization.

\section{Functional differentiation as a source of structural variety}

There is no need to associate functional differentiation with increasing global homogeneity. On the contrary, functional differentiation is entirely compatible with variable structures - within subsystems. That is because functional differentiation means the specialization of social structures with regard to specific problems. If structures have a 'function' 
that means that they contribute to solving a particular problem. For instance, political structures are related to problems of making collectively binding decisions, and economic structures deal with problems of scarcity; however, the structures cannot be derived from the problems - there are always different ways of addressing a particular problem. The crucial point of functionalist perspectives - in both science and society - is to draw attention to equivalent strategies of problem solving, i.e. to functional equivalences (Luhmann 1970). If subsystems are 'functional systems' their structures are variable to the extent that they are related to a particular function. In other words, functional specialization stimulates the search for alternative solutions for particular problems.

Alternatives react to particular constraints. What may be a good solution in one context may not be possible or permissible in another one. Restrictions of economic transactions are a case in point. Although religious considerations may not be of paramount importance in global financial markets, they have economic significance in certain regions, for instance if religious beliefs dictate whether certain economic transactions such as interest payments are permissible at all. The seemingly restrictive stance of Islam towards loan and interest is a case in point (Leins 2010). A 'good loan' in Islamic law is an interest-free loan and deposits are meant for safe-keeping only. The instruments of 'Islamic finance' provide alternative solutions (Taqī 'Uśmānī 2002; Warde 2010). For instance, the murabaha instrument mirrors the function of a mortgage while avoiding interest payments: Instead of granting a loan, the bank buys the property and sells it to the client at cost plus a declared profit. The total amount may then be paid in instalments but technically it consists only of a principal and does not involve interest payments. Obviously, however, the mark-up of the original price is an equivalent to that. Islamic finance thus provides functional equivalents to solve financial problems under specific religious constraints. It does so by developing and employing financial instruments that are compatible with religious criteria rather than by abolishing economic rationality altogether.

For another example of the variability of functional subsystems we may refer to Luhmann's analysis of party systems (Luhmann 2010, 282ff.). ${ }^{3}$ Written during the heyday of the Cold War, the analysis focuses on one-party and multi-party systems and submits them to a functional analysis, which assumes that both kinds of party systems must solve particular political problems. They are in some way 'functionally equivalent' despite their obvious differences.

3 Although the topic of world society is not addressed in this work, which is a posthumous publication of a manuscript written during the late 1960s, it is pertinent to our discussion. The above-mentioned issue is just one among a couple of other references to the politics in Socialist countries and also in the developing world. 
Whereas taking a normative stance would usually result in questioning both the desirability and the viability of a one-party system, a functional analysis allows us to see it as a viable alternative. Luhmann argues that party systems address problems of 'political complexity' by securing societal support for changing political programmes including the recruitment and replacement of leaders. In order to achieve that they must be able to process social conflicts and to produce options for collective decision-making; on top of that, one can argue that the adaptation to a changing social environment requires political alternatives to be kept and remembered and not to be discarded entirely. That is quite obviously the case in multi-party systems, in which different parties represent different choices; and in which the distinction of government parties and opposition parties provides a pool of variety that can be drawn upon in order to represent societal pluralism. Yet how does that work in one-party systems? They cannot tolerate the same level of manifest contradiction that multi-party systems institutionalize through the diversity of political parties: There is one and only one party doctrine. But a oneparty system, too, must be able to change course. Luhmann argues that flexibility is introduced by way of distinguishing between 'ideology' and 'practice:' The ideology is considered comprehensive and stable but practice changes, and therefore adaptations remain possible. The way in which Luhmann analyses the model of the one-party system as a functionally equivalent alternative clearly indicates the appreciation of the rather more complicated yet viable institutionalization of capacities to learn and adapt. From the perspective of the function of the political system - to provide the capacity for collectively binding decisions -, it is therefore possible and necessary to conceive different, functionally equivalent organizational forms. Each type of party system has its own side-effects, which have to be borne by society as a whole and which may limit which kinds of solutions are sustainable, but in principle there is no one best institutional model.

These two examples from the political and economic realm should suffice to illustrate the argument put forward in this section: From the perspective of the theory of functional differentiation there is no need to expect homogeneity - at least, if functionalism is taken seriously. Differentiation with reference to specific problems (i.e. functions) does not presuppose that there is only one solution. Rather, functional comparison entails the discovery of alternatives or functional equivalents. The examples of party systems and religiously constrained financial instruments show that the choice between alternative structures is bound up with the rationalities of particular subsystems: A party system has to make sense as a specific structure within the political realm, whereas murabaha can only be understood as an economic 
institution whose meaning is neither political nor strictly religious. The search for (or more precisely: the discovery and evolutionary selection of) alternatives is therefore guided or even constrained by functional differentiation. However, this is also the kind of constraint that enables innovation by specifying the context in which particular solutions make sense.

Functionally equivalent structures in political and economic contexts have been extensively discussed, regarding both varieties of government (Hague/Harrop 2013) and varieties of capitalism (Hall/Soskice 2001; Hampden-Turner/Trompenaars 1993). Similar varieties can easily be spotted in other realms, too, for instance in education (Arnove/Torres 2007; Schriewer 2005), in religion (Beyer 1994; Beyer/Beaman 2007; Petzke 2013) and also in sports (Giulianotti 1999; Giulianotti/Robertson 2009; Werron 2010). This kind of variety obviously does not imply a revocation of functional differentiation. The distinction of subsystems and their respective rationalities are taken for granted, but different viable solutions are found and institutionalized within their respective domains. Insofar as different structural constellations can be regarded as functionally equivalent, they may be considered varieties rather than variations: There is no 'standard' from which variations could be derived and against which they could be measured. Particular institutional solutions, such as liberal democracy or a stratified education system may be more successful than others in particular historical or regional constellations. Within their immediate functional context, however, they are merely one alternative among others.

\section{Variations of coupling and decoupling}

Another source of diversity resulting from functional differentiation concerns the relationships between subsystems. As societal subsystems are considered autonomous or 'autopoietic,' they cannot directly control one another. However, mutual influences and interdependencies lead to 'structural couplings' that link subsystems on a permanent basis (Luhmann 1992; 1997, 776ff.). Concerning at least three prominent domains of modern society - the political, the legal and the economic system - there are specific 'institutions' that specify the structural couplings among them: Politics and the law are coupled through the constitution, politics and the economy through taxes and transfers, and the legal and the economic system through property and contract. From a world society perspective, one might ask to what extent those institutions exist at a global level, e.g. in the form of a global constitution (Fischer-Lescano 2005). However, such global forms are still few and far between. Most forms of structural coupling are local or 
country-specific: Constitutions are promulgated by the legislation of particular nation-states, taxes and transfers differ from country to country, and so do contract laws. That is not just a matter of those particular forms of structural coupling being somewhat state-dependent. For instance, the structural coupling between the economic and the education system rests upon credentials and certificates, which are only partly regulated by legislation but still show variations closely correlated with political borders. 4

The concrete manifestations of structural coupling therefore show a great deal of variation. With regard to constitutions, contracts and taxes, we may indeed speak of variations because their manifestations do not arise independently but in a process of imitation, diffusion and adaptation. That may also explain why constitutions, taxation and contracts not only exist almost everywhere but also are not quite as diverse as one might expect. Apart from language and the precise wording, many constitutions follow similar models - and even change according to global trends (Heintz/Schnabel 2006; Beck/Drori/Meyer 2012). Civil law and tax systems, as well as educational certificates and school curricula are not standardized around the world but there is markedly less diversity than cultural and economic differences would lead us to expect (Meyer 1987). That kind of homogeneity in various domains of world society is one of the main conjectures of the world polity approach and by now well documented by empirical research (Meyer 1980; Meyer/Kamens/Benavot 1992; Meyer/Boli/Thomas/Ramirez 1997).

Together, the varieties of functionally equivalent solutions in societal subsystems and the more or less subtle variations of a rather uniform set of forms of structural coupling come close to what may be regarded as 'varieties of modernity' (Schmidt 2006; 2013): In contrast to the argument for 'multiple modernities' (Delanty 2004; Eisenstadt 2000) this label is meant to highlight the common core of a 'global modernity,' against which variations in terms of functionally specific but culturally heterogeneous institutional patterns are brought into relief. Accordingly, we can distinguish at least two different but interacting sources of structural diversity in world society: varieties of functionally equivalent institutional solutions, on the one hand, and the variation of forms of structural coupling on the other hand. Both observations can be accommodated if we regard global functional differentiation as a framework for

4 That becomes even more obvious if political borders shift or expand and efforts to harmonize educational certificates follow suit, as has been the case in the European Union following the infamous 'Bologna reform.' There are, of course, also trends towards global homogenization to facilitate global mobility - and, presumably, to provide adequate structural coupling with a globalized economy. 
providing contexts for variation and for enabling regional diversity of the concrete manifestations of structural coupling.

However, this picture of world society characterized by functional differentiation as the backbone of variety and variation is still incomplete. It is based on too superficial an analysis of both the structures within functional subsystems and the forms of structural coupling among them. While we have emphasized functional differentiation as a source of diversity, a look at, say, politics around the world might still lead to the conclusion that there is a great deal of homogeneity -- for instance regarding the worldwide diffusion of democracy (Wejnert 2005). And in a similar vein, as mentioned above, the forms of structural coupling do not seem to vary that much after all. Any conclusion that global functional differentiation is even more uniform than expected would be premature. That is because the underlying observation of homogeneity takes formal structures at face value. But what does it mean that Colombia has a constitution or that Thailand is a democracy? Is Thailand's political system more or less the same as the one in the Netherlands and are the political and the legal system 'structurally coupled' through a constitution in Colombia?

It is insufficient to gauge the degree and variability of functional differentiation based on observations of formal institutions because the 'decoupling' between formal structures and actual practices is widespread in world society: 5 Individuals, organizations and states subscribe to global norms and cultural scripts but fail to live up to them in practice. For instance, governments seek to have a full set of ministries, no matter whether they correspond to local conditions. In official statistics, however, even a country with fewer than a dozen scientists is likely to have a ministry of science (Jang 2000). While formal structures such as models of democracy, administrative procedures and organizational technologies are heavily globalized and continue to spread across the world, they frequently only affect the surface of social reality. Global expectations - mainly of Western origin - are often ill-adapted to local conditions elsewhere but at the same time constitute the backbone of membership in the world polity. Therefore they can only be fulfilled by employing some degree of 'hypocrisy' (Brunsson 1989): States have ministries of education that participate in global conferences and develop curricula according to international standards - but cannot provide chairs, writing desks or books (Meyer/Nagel/Snyder 1993). They also subscribe to international conventions such as the UN

5 The concept of decoupling is an important element in the neo-institutionalist theory of formal organizations (Meyer/Rowan 1977) and was taken up by the world polity perspective (Meyer/Boli/Thomas/Ramirez 1997). 
Declaration of Human rights - but are unable to ensure that their civil servants and police officers adhere to them (Hafner-Burton/Tsutsui 2005).

From the perspective of differentiation theory, it is important to note that decoupling affects both the performance of subsystems and the actual consequences of structural coupling. Functional subsystems have official scripts and self-descriptions but there may be entirely different or countervailing informal structures that are more relevant for directing social expectations and practices (Holzer 2006, 272ff.; 2015). Structural coupling may seemingly be based on a formal structure but in fact be achieved by other means: For instance, educational certificates may exist although they do not play a role for careers in the informal economy like, for instance, in Peru (Burch 2013); or a constitution may fail to effect any structural coupling because the political system dominates the law despite constitutional provisions, like, for instance, in Brazil (Neves 1992). In other words, there are regionally specific informal substitutes for structural coupling - or no such coupling at all - despite seemingly 'modern' institutions.

\section{The ambiguous primacy of functional differentiation}

In the preceding section I have argued that comparative inquiries based on formal structures may be deceptive and that detailed empirical analyses are likely to discover more, sometimes less obvious forms of diversity. The argument so far has been predicated on the assumption that functional differentiation is indeed the primary mode of differentiation at the global level. There are of course theoretical challenges (Wallerstein 1974/1980/1989) as well as principled objections (Münch 2011) to this assumption. Both are interdependent: Theory stimulates the search for particular data and the availability of data determines what kind of theoretical questions can be answered. For instance, the overwhelming empirical evidence of global inequalities is often taken to confirm that world society is best described in terms of its social stratification. Yet both stratification and functional differentiation are compatible with economic and other forms of inequality (Luhmann 1985; Stichweh 2005).

It is questionable whether statistical data are instructive at all in this regard. The differentiation of society is less a matter of aggregate figures than one of everyday situations: If differentiation makes a difference, it does so for any communication or social situation. If a society is differentiated in a particular way that means that certain distinctions - e.g. between tribes, social 
classes or occupational roles - are routinely employed and enacted in everyday social action. That makes it difficult, for instance, to regard stratification as a global social structure - rather than as a statistical aggregate - in world society: That would mean that one's class or caste informs and governs social contacts not just locally or regionally but also globally. In fact, however, someone who participates in an economic transaction, reads an article in a scientific journal or assesses the equivalence of a university degree will usually not even be aware of the 'class' of the other person or similar social distinctions. They may well be either irrelevant or simply unknown in many social contacts. A great deal of communication in modern society especially consequential communication - is mediated communication among strangers in the context of a particular subsystem. That results in widespread indifference towards other social distinctions. If scientific communication can be distinguished from an economic transaction at all, it is hard to see how that kind of specialization would not lead to the marginalization or subordination of other forms of differentiation.

One might be led to the conclusion that functional differentiation has achieved 'primacy' over other forms of differentiation (Luhmann 2005, 247). Those other forms of differentiation would then be either strictly secondary, such as the segmentation of the functionally differentiated global political system into segmental territorial units, which themselves are differentiated according a centre/periphery distinction between the government as the centre of decisionmaking and social movements as the claims-making periphery (Luhmann 2000); or they would be relegated to remnants of the past that continue to exist but do not determine the dominant structure of society anymore, as in the case of stratification into social classes (Luhmann 1985; Kieserling 2006). Against this interpretation of the significance of functional differentiation, two objections need to be raised: The presumed dominance of functional differentiation could, first, itself be limited in scope and might thus not be quite as universal as stated. Second, the primacy might be a communicative artefact produced by other forms of differentiation disguised as functional differentiation.

First, the scope of functional differentiation is not geographically limited, although limits of functional differentiation are most clearly visible in particular regions. Luhmann suggests that inclusion/exclusion might be considered kind of 'supercode' that limits the scope of functional differentiation to the side of inclusion (Luhmann 1995; Stichweh 1997). However, the idea that there is no functional differentiation in zones of exclusion like the 'favelas' in Brazil is not very convincing. Even under such circumstances, economic transactions take place and people may participate in religious communities, consume the products of the mass media and engage in 
sporting events. The ways in which persons are included may, however, differ, for instance if informal networks are the primary vehicles through which access to functional subsystems is granted. It would then be more plausible to conceive of the limited scope of functional differentiation in terms of a centre/periphery structure: In the centre, direct inclusion into subsystems is possible while in the periphery mediated inclusion through networks prevails (Holzer 2007). The 'full realization' of functional differentiation would then be limited to the centre, which, it is important to note, is not necessarily a geographical location but may as well be a node of relations, i.e. the 'hub' of globally connected communication. The homogenizing and universalizing effects of functional differentiation are most clearly articulated at a global level or, more precisely, in the 'centres' of functional subsystems. In more 'peripheral' regions, the universalism of subsystems or even functional differentiation as such may be more of a variable.

Second, the institutionalization of functional differentiation may be circumscribed by other forms of differentiation that effectively guide action but are disguised and renounced because functional differentiation is regarded as a legitimate formal structure. The structural implications of functional differentiation are then officially adopted but they are more or less undermined by other distinctions that are informally institutionalized. The problem of caste in India - undoubtedly a form of stratification - is a case in point. According to most observers, castes are relevant social distinctions for practical purposes despite not being legitimate forms of differentiation anymore. But as an example reported by Sebring (1969) shows, caste may nonetheless be an important factor in communication: Sebring discusses the case of a small tea shop in Northern India in which the caste of customers matters. The shop owner has to cope with purity rules that forbid a higher caste individual to drink from a glass previously used by someone from a lower caste. Yet legislation and economic rationality forbid keeping lower caste individuals (in this case from the Shilpkar caste) from patronizing the shop. An informal arrangement exists by which Shilpkars clean their glass themselves after using it and thus remove the 'impurity.' The shop owner is therefore inclined to sell tea only to those Shilpkars who know that they have to wash their glasses. For strangers, he has to rely on 'caste indicators' to judge them and if he suspects them to be of a lower caste he will find an excuse not to serve them because he cannot ascertain that they are familiar with the washing routine. Thus, the economic rationality that would certainly recommend serving strangers as well is obstructed by issues of stratification, and functional differentiation itself is in a way subordinated to caste distinctions. 
Limitations to the scope and to the factual institutionalization of functional differentiation are hard to deny. The often clandestine way in which expectations of functional (and corresponding structural) differentiation are undermined follows the pattern of 'informal structures' that serve as substitutes for (but sometimes also as competitors to) particular forms of structural coupling. Corresponding gaps between expectations and performance require either elaborate practices of disguise - or the promise that mismatches are only temporary. Such a promise was (and is) at the core of classic modernization theory, but we cannot take that for granted anymore. However, recent research on decoupling, for instance in the sphere of human rights, has shown that 'empty promises' may serve as the levers to align practices and expectations, albeit not completely (Hafner-Burton/Tsutsui 2005; Hafner-Burton/Tsutsui/Meyer 2008; Cole 2012). For the time being, we should therefore regard the primacy of functional differentiation as a heuristic device for empirical analysis rather than as an accomplished and established fact: At the global level, it seems to be the only candidate to describe world society, because alternatives, e.g. in terms of a stratified hierarchy, are even less plausible; at the local and regional level, however, it remains just as important to analyse the ways in which the expectations of functional subsystems are reconciled with local exigencies and contradicting expectations.

\section{Conclusion}

I have argued that differentiation theory offers a range of concepts to acknowledge and to address structural diversity in world society. Functional differentiation is not antithetical to variation because the functional perspective stimulates the search for other, equivalent alternatives. Functional differentiation therefore gives rise to varieties of institutional arrangements that are geared towards solving particular societal problems. Based on a narrow and linear concept of modernity, classical modernization theory has underestimated to what extent different institutional structures may be functionally equivalent. Instead it sought to measure progress in each of society's sectors so as to be able to gauge the extent to which the economy, the polity, education and so on were 'modernized.' That might not be the most fruitful way to assess modernity from a sociological perspective (even though it still is very popular among international organizations collecting all kinds of data about progress). All too often it goes hand in hand with the assumption that a particular (Western) model is the standard of measurement. A functional analysis, in contrast, analyses different solutions in their own right, 
but with a view towards the particular side-effects of any solution in its particular social environment.

A different set of phenomena, which concerns variations of institutional models, shows more resemblance to classic view of modernization. As world polity analysis has pointed out, there is a striking global isomorphism of institutional arrangements, often associated with the modern nation-state. From the perspective of differentiation theory, at least a significant part of these phenomena is related to forms of 'coupling' between societal subsystems. The political, economic, legal and educations systems are linked in ways that are both very general (e.g. all states levy taxes) and highly specific (e.g. actual taxation varies widely). Complementary to such variations of structural coupling, another source of variations arises from the 'decoupling' of formal structures and actual practice: While modern institutions show a high degree of similarity at the level of official indicators and self-descriptions, less obvious informal structures may result in more diverse actual practices.

The focus of classical modernization theory has been on the comparative analysis of individual countries, whereas world society theory has to conceive of modernity as a global phenomenon. Thus, 'modernity' is not a feature of societal sectors but of society as a whole. World society may be regarded as 'modern' to the extent that the differentiation into functional subsystems is its 'primary' mode of differentiation. I have argued that such a view is plausible because other forms of differentiation cannot seriously be regarded as global structures. However, other forms of differentiation do not disappear and the combination of forms of differentiation therefore remains a considerable source of variation in world society. 


\section{References}

Arnove, Robert F. / Torres, Carlos Alberto (2007): Comparative Education: The Dialectic of the Global and the Local. Lanham, MD.

Beck, Colin J. / Drori, Gili S. / Meyer, John W. (2012): World influences on human rights language in constitutions. A cross-national study. International Sociology 27, 483-501.

Beyer, Peter (1994): Religion and Globalization. London.

Beyer, Peter / Beaman, Lori (2007): Religion, Globalization, and Culture. Leiden.

Brunsson, Nils (1989): The Organization of Hypocrisy. Talk, Decisions and Actions in Organizations. Chichester.

Burch, Janet (2013): Formen wirtschaftlicher Praktiken. Globalisierung und Informalität am Beispiel von Lima, Peru. Luzern: Universität Luzern.

Cole, Wade M. (2012): Human rights as myth and ceremony? Reevaluating the effectiveness of human rights treaties, 1981-2007. American Journal of Sociology 117, 1131-1171.

Delanty, Gerard (2004): Multiple modernities and globalization. Protosociology 20, 165-185.

Eisenstadt, Shmuel N. (2000): Multiple modernities. Daedalus 129, 1-29.

Fischer-Lescano, Andreas (2005): Globalverfassung. Weilerswist: Velbrück.

Giulianotti, R. (1999): Football. A Sociology of the Global Game. Cambridge: Polity.

Giulianotti, Richard / Robertson, Roland (2009): Globalization and Football. London: Sage.

Hafner-Burton, Emilie M. / Tsutsui, Kiyoteru (2005): Human rights in a globalizing world. the paradox of empty promises. American Journal of Sociology 110, 1373-1411.

Hafner-Burton, Emilie M. / Tsutsui, Kiyoteru / Meyer, John W. (2008): International human rights law and the politics of legitimation. Repressive states and human rights treaties. International Sociology 23, 115-141.

Hague, Rod / Harrop, Martin (2013): Comparative Government and Politics. An Introduction. Houndmills: Palgrave Macmillan.

Hall, Peter A. / Soskice, David W. (2001): Varieties of Capitalism. The Institutional Foundations of Comparative Advantage. Oxford: Oxford University Press.

Hampden-Turner, Charles / Trompenaars, Alfons (1993): The Seven Cultures of Capitalism. New York: Doubleday.

Heintz, Bettina / Schnabel, Annette (2006): Verfassungen als Spiegel globaler Normen? Eine quantitative Analyse der Gleichberechtigungsartikel in nationalen Verfassungen. Kölner Zeitschrift für Soziologie und Sozialpsychologie 58, 685-716. 
Holzer, Boris (2006): Spielräume der Weltgesellschaft. Formale Strukturen und Zonen der Informalität, in: Thomas Schwinn (ed.), Die Vielfalt und Einheit der Moderne. Kulturund strukturvergleichende Analysen. Wiesbaden: VS, 259-279.

Holzer, Boris (2007): Wie 'modern' ist die Weltgesellschaft? Funktionale Differenzierung und ihre Alternativen. Soziale Systeme 13, 355-366.

Holzer, Boris (2015): The Two Faces of World Society, in: Boris Holzer / Fatima Kastner / Tobias Werron (eds.), From Globalization to World Society. London/New York: Routledge, 37-60.

Jang, Yong Suk (2000): The worldwide founding of ministries of science and technology, 1950-1990. Sociological Perspectives 43, 247-270.

Kieserling, André (2006): Klasse und Klassengesellschaft. Zur Entkopplung zweier Begriffe, in: Karl-Siegbert Rehberg (ed.), Soziale Ungleichheit, Kulturelle Unterschiede. Verhandlungen des 32. Kongresses der Deutschen Gesellschaft für Soziologie in München 2004. Frankfurt a.M./New York: Campus, 4425-4436.

Leins, Stefan (2010): Zur Ethik des islamischen Finanzmarktes. Zeitschrift für Wirtschaftsund Unternehmensethik 11, 66-75.

Luhmann, Niklas (1970): Funktionale Methode und Systemtheorie, in: Niklas Luhmann, Soziologische Aufklärung 1: Aufsätze zur Theorie sozialer Systeme. Köln/Opladen: Westdt. Verlag, 31-53.

Luhmann, Niklas (1985): Zum Begriff der sozialen Klasse, in: Niklas Luhmann (ed.), Soziale Differenzierung: Zur Geschichte einer Idee. Opladen: Westdt. Verlag, 119-162.

Luhmann, Niklas (1992): Operational closure and structural coupling: the differentiation of the legal system. Cardozo Law Review 13, 1419-1441.

Luhmann, Niklas (1995): Inklusion und Exklusion, in: Niklas Luhmann, Soziologische Aufklärung 6. Die Soziologie und der Mensch. Opladen: Westdt. Verlag, 237-264.

Luhmann, Niklas (1997): Die Gesellschaft der Gesellschaft. Frankfurt a.M.: Suhrkamp. Luhmann, Niklas (2000): Die Politik der Gesellschaft. Frankfurt a.M.: Suhrkamp.

Luhmann, Niklas (2005): Einführung in die Theorie der Gesellschaft. Heidelberg: Carl-AuerSysteme Verlag.

Luhmann, Niklas (2010): Politische Soziologie. Berlin: Suhrkamp.

Meyer, John W. (1980): The world polity and the authority of the nation-state, in: Albert Bergesen (ed.), Studies of the Modern World System. New York: Academic Press, 109137. 
Meyer, John W. (1987): The world polity and the authority of the nation-state, in: George M. Thomas / John W. Meyer / Francisco O. Ramirez / John Boli (eds.), Institutional Structure. Constituting State, Society, and the Individual. Newbury Park: Sage, 41-70.

Meyer, John W. / Boli, John / Thomas, George M. / Ramirez, Francisco O. (1997): World society and the nation-state. American Journal of Sociology 103, 144-181.

Meyer, John W. / Kamens, Davin H. / Benavot, Aaron (1992): School Knowledge for the Masses. World Models and National Primary Curricular Categories in the Twentieth Century. London: Falmer.

Meyer, John W. / Nagel, Joane / Snyder, Jr. Conrad W. (1993): The expansion of mass education in Botswana. local and world society perspectives. Comparative Education Review 37, 454-475.

Meyer, John W. / Rowan, Brian (1977): Institutionalized organizations: formal structure as myth and ceremony. American Journal of Sociology 83, 340-363.

Münch, Richard (2011): Die Weltgesellschaft im Spannungsfeld funktionaler, stratifikatorischer und segmentärer Differenzierung, in: Gert Albert / Steffen Sigmund (eds.), Soziologische Theorie kontrovers. Wiesbaden: VS, 283-298.

Neves, Marcelo (1992): Verfassung und Positivität des Rechts in der peripheren Moderne. Eine theoretische Betrachtung und eine Interpretation des Falls Brasilien. Berlin: Duncker \& Humblot.

Petzke, Martin (2013): Weltbekehrungen. Zur Konstruktion globaler Religion im pfingstlichevangelikalen Christentum. Bielefeld: transcript.

Robertson, Roland (1992): Globalization. Social Theory and Global Culture. London: Sage.

Schmidt, Volker H. (2006): Multiple modernities or varieties of modernity? Current Sociology 54, 77-97.

Schmidt, Volker H. (2013): Globale Moderne. Skizze eines Konzeptualisierungsversuchs, in: Ulrich Willems / Detlef Pollack / Helene Basu / Thomas Gutmann / Ulrike Spohn (eds.), Moderne und Religion. Kontroversen um Modernität und Säkularisierung. Bielefeld: transcript, 27-73.

Schriewer, Jürgen (2005): Wie global ist die institutionalisierte Weltbildungsprogrammatik? Neo-institutionalistische Thesen im Licht kulturvergleichender Analyse, in: Bettina Heintz / Richard Münch / Hartmann Tyrell (eds.), Weltgesellschaft: Theoretische Zugänge und empirische Problemlagen. Stuttgart: Lucius \& Lucius, 415-441. 
Schwinn, Thomas (2004): Von der historischen Entstehung zur aktuellen Ausbreitung der Moderne. Max Webers Soziologie im 21. Jahrhundert. Berliner Journal für Soziologie 14, $527-544$.

Sebring, James M. (1969): Caste indicators and caste identification of strangers. Human Organization 28, 199-207.

Stichweh, Rudolf (1997): Inklusion/Exklusion, funktionale Differenzierung und die Theorie der Weltgesellschaft. Soziale Systeme 3, 123-136.

Stichweh, Rudolf (2000): Die Weltgesellschaft. Soziologische Analysen. Frankfurt a.M.: Suhrkamp.

Stichweh, Rudolf (2005): Erzeugung und Neutralisierung von Ungleichheit durch Funktionssysteme, Inklusion und Exklusion. Studien zur Gesellschaftstheorie. Bielefeld: transcript, 163-177.

Taqī 'Usmānī, Muhạmmad (2002): An Introduction to Islamic Finance. The Hague: Kluwer. Wagner, Gerhard (1996): Die Weltgesellschaft. Zur Kritik und Überwindung einer soziologischen Fiktion. Leviathan 24, 539-556.

Wallerstein, Immanuel (1974/1980/1989): The Modern World System. Volumes I, II, III. Cambridge: Cambridge University Press.

Warde, Ibrahim (2010): Islamic Finance in the Global Economy. Edinburgh: Edinburgh University Press.

Wejnert, Barbara (2005): Diffusion, development, and democracy, 1800-1999. American Sociological Review 70, 53-81.

Werron, Tobias (2010): Der Weltsport und sein Publikum. Zur Autonomie und Entstehung des modernen Sports. Weilerwist: Velbrück. 